\title{
PENEMUAN HUKUM DALAM PERKARA PIDANA ADAT
}

\author{
Hwian Christianto ${ }^{1}$
}

\begin{abstract}
Indonesia is one of nations full of culture values. The diversity of this culture values is still breathing and keep growing in society. As a country adopts civil law system, an Indonesian judge must keep standing on each clear and codified od law's decisions. On the other hand, this system brings a benefit to the law certainty on the society rights from the government. While on the other side, there is a weakness in manifesting a justice for the society because there is not always if the rules are capable enough in reserving the developments, especially the norms admitted by society. This fact of course will bring a serious effect to the criminal law when there are so many custom cases with public aspect could not be judged and legality as the reason or there is no law's decision which regulate clearly. Over here the understanding of the founding by the judge in a "adat delict" plays an important role as an effort to manifest the supremacy of law and justice.
\end{abstract}

Keyword: lawfinding, adat delict, legality

\begin{abstract}
Abstrak
Indonesia merupakan salah satu negara yang penuh nilai-nilai budaya. Keragaman nilai budaya ini masih bernapas dan terus berkembang di masyarakat. Sebagai sebuah negara yang mengadopsi sistem civil law, seorang hakim Indonesia harus berpendirian jelas terhadap setiap keputusannya dan dikodifikasikan Di sisi lain, sistem ini membawa manfaat bagi kepastian hukum dari pemerintah terhadap hak-hak masyarakat. Sementara di sisi lain, ada kelemahan dalam mewujudkan keadilan bagi masyarakat karena tidak selalu menyediakan aturan yang cukup mampu dalam perkembangannya, terutama norma yang diakui oleh masyarakat. Fakta ini tentu saja akan membawa dampak serius terhadap hukum pidana ketika ada kasus adat dengan begitu banyak aspek publik tidak bisa dihakimi dan legalitas sebagai alasan atau ada keputusan hukum yang mengatur dengan jelas. Di sini pemahaman pendirian hakim dalam "adat delik" memainkan peran penting sebagai upaya untuk mewujudkan supremasi hukum dan keadilan.
\end{abstract}

Kata kunci: penemuan hukum, delik adat, legalitas

1 Dosen Laboratorium Hukum Pidana Fakultas Hukum Universitas Surabaya. Alamat kontak: hw_christianto@ubaya.ac.id. 


\section{Pendahuluan}

Indonesia seperti halnya negara-negara lain di dunia mempunyai ciri khas di dalam mengatur masyarakatnya sehingga mempunyai hukum sendiri. Tiap-tiap bangsa mempunyai satu tatanan nilai yang terwujud di dalam hukum tersendiri ${ }^{2}$. Bahkan jauh sebelum Bangsa Belanda datang ke Indonesia, masyarakat Hindia Belanda (sebutan Indonesia jaman dahulu) di tiap masyarakatnya telah membentuk dan mengakui satu hukum yang berlaku. Hukum yang berlaku di masyarakat ini padqa gilirannya mendapatkan perubahan-perubahan yang sangat mendasar terkait dengan adanya pendudukan pemerintah kolonial Belanda yang dengan paksa menerapkan hukum kolonialnya di Hindia Belanda. Hingga masa kemerdekaan pun pengakuan terhadap nilai-nilai hukum adat masih belum muncul di dalam peraturan perundang-undangan Indonesia. Dengan di berlakukannya asas konkordansi secara legalitas formal, bangsa Indonesia memberlakukan hukum Belanda yang selama ini berlaku dengan beberapa perubahan yang di perlukan. Perubahan-perubahan ini dilakukan sebagai upaya untuk menyeleraskan ketentuan hukum yang ada itu dengan nilai-nilai hukum yang berlaku bagi bangsa Indonesia. Pasal II aturan peralihan UUD 1945 dan UU No. 1/Pnps/1965 menjadi dasar bagi pemberlakuan dan penyerasian hukum hasil konkordansi itu menjadi hukum nasional bangsa Indonesia. Hanya saja semangat ini tidak di teruskan oleh peraturan perudang-undangan sebagai pelaksana secara langsung, baru dengan di undangkannya UU Darurat No. 1 Tahun 1951 secara khusus pasal 5 ayat (3) huruf $\mathrm{b}$, hukum adat di mungkinkan sebagai dasar materiil untuk mengadili perkara pidana adat di peradilan umum.

Permasalahan yang timbul adalah sampai sejauh manakah kegiatan penemuan hukum oleh hakim dalam bidang hukum pidana adat itu di akui keberadaannya. Apakah keberadaan UU Darurat No. 1 Tahun 1951 membawa kemudahan bagi hakim dalam melakukan penemuan hukum ataukah justru membawa permasalahan bagi hakim dalam melakukan penemuan hukum.

\section{Pembahasan}

Hukum yang berlaku di masyarakat ini pada dasarnya merupakan salah satu perwujudan dari kebudayaan di masyarakat. Perwujudan kebudayaan ini di dalam masyarakat dapat di lihat pertama melalui kompleks ide, gagasan, nilai-nilai, norma-norma, peraturan dan sebagainya, kedua sebagai aktivitas kelakuan berpola dari manusia dalam masyarakat dan Ketiga sebagai benda-benda hasil karya manusia. $^{3}$

${ }^{2}$ Van Apeldoorn, "Inleiding tot de studie van het Nederlandse Recht", 17e herziene druk, bewerkt door Mr. J.C.M. Leyten, Uitgeversmaatschappij W.E.J. Tjeenk Willink, Zwolle, 1972, hal. 6.

3 Koentjoroningrat, "Kebudayaan, Mentalitet dan Pembangunan", (Jakarta: Gramedia, 1974), hal. 15. 
Dari ketiga perwujudan kebudayaan ini, bentuk perwujudan pertama lebih memberikan pemahaman awal tentang keberadaan hukum di dalam kebudayaan itu. Perwujudan kebudayaan dalam bentuk pertama ini lebih menekankan pada sistim norma-norma hukum yang di akui dan di berlakukan oleh masyarakat sehingga hukum secara khusus pun berlaku. Koentjoroningrat menyebut hukum secara khusus ini dengan istilah "adat tata kelakuan" yang berisi kebudayaan idiil di dalam masyarakat sekaligus berfungsi sebagai tata kelakuan yang mengatur, mengendali, dan memberi arah kepada kelakuan dan perbuatan manusia dalam masyarakat. ${ }^{4}$ Hermien Hadiati Koeswadji lebih menjelaskan hukum yang berlaku ini sebagai:

\begin{abstract}
Sistim nilai-nilai budaya ... terdiri dari konsep-konsep yang hidup dalam alam pikiran sebagian besar warga masyarakat yang merupakan warga dari kebudayaan yang bersangkutan, yaitu mengenai hal-hal yang harus mereka anggap penting dan bernilai dalam hidup. ${ }^{5}$
\end{abstract}

Di dalam pemahaman inilah sebenarnya hukum asli dari bangsa Indonesia sudah hidup dan berkembang di masyarakat sebagai hukum yang tidak tertulis atau yang lebih dikenal dengan hukum adat.

Pada kasus terdapat pelanggaran yang terjadi di dalam hukum adat dan menimbulkan kerugian bagi anggota masyarakat maka masyarakat adat dengan serta merta akan memberlakukan hukum adatnya sebagai dasar untuk mengadili suatu perbuatan yang dapat dikatakan sebagai delik adat. Apabila pemahaman akan delik adat ini di bandingkan dengan konsep "strafbaarfeit" seperti yang terdapat di dalam hukum pidana kodifikasi ternyata akan menemui beberapa permasalahan. Jika pengertian "straffbaarfeit" itu di rumusakan sebagai "setiap perbuatan yang oleh pembentuk undang-undang ditetapkan sebagai perbuatan yang dapat dipidana" tidak berarti pengertian "delik adat" juga sama. Mengingat perbuatan-perbuatan yang terdapat di dalam hukum adat tidak tertulis ini di tetapkan juga secara tidak tertulis.

Untuk mengantisipasi hal ini perlu dikemukakan pendapat Moeljatno mengenai arti dari strafbaarfeit, "perbuatan-perbuatan pidana ini menurut wujud atau sifatnya adalah bertantangan dengan tata atau ketertiban yang dikehendaki oleh hukum, mereka adalah perbuatan yang melawan hukum" "7 atau dengan difinisi yang serupa perbuatan pidana atau delik itu merupakan perbuatan yang dilarang oleh suatu aturan hukum larangan mana di sertai ancaman (sanksi)

${ }^{4}$ Ibid.

${ }^{5}$ Ibid, hal. 40.

"Alida M.Bos, "Het Begrip Straffbaarfeit in de Rechtsvorming", Netherland: KluwerDeventer, 1971), hal. 4.

${ }^{7}$ Moeljatno, "Asas-asas Hukum Pidana", (Jakarta: Rineka Cipta, 2005), hal. 5. 
berupa pidana tertentu, bagi barangsiapa melanggar larangan tersebut. Dengan mengikuti pandangan Moeljatno ini, pemahaman tentang perbuatan pidana atau delik menjadi lebih mendasar pada maksud hukum pidana itu sendiri. Kesalahan yang selama ini di pahami ketika hukum pidana selalu di samakan dengan peraturan tertulis bukan pada sifat dilarangnya perbuatan dan di ancamnya pelaku dengan sanksi pidana. Dari pengertian "strafbaarfeit" ini, delik adat dapat di masukkan di dalam pemahaman sebagai perbuatan yang dilarang oleh ketentuan hukum adat yang berlaku pada saat itu.

\section{Asas Legalitas dan Delik Adat}

Pemahaman terhadap makna asas legalitas sebenarnya telah mengalami perkembangan yang signifikan. Perkembangan bermula dari Asas legalitas sebagai Jaminan agar Pemerintah tidak Sewenang-wenang (menentang absolutisme Raja), berkembang menjadi Perlindungan Proses Hukum yang Jelas (menyangkut pengaturan mengenai Hak Asasi Manusia dalam Bill of Right Virginia tahun 1776) dan perkembangan terakhir asas legalitas sebagai hukum pidana materiil ${ }^{8}$ yang memahami "nullum delictum nulla poena sine preavia lege poenali" tidak hanya sebatas undang-undang atau hukum tertulis. Tentu saja pemberlakuan asas legalitas disini harus dipahami menurut weltanschauung dari bangsa Indonesia sendiri ${ }^{9}$ sehingga dapat diterapkan pada kasus pidana adat. Asas legalitas harus di pahami menurut nilai-nilai hukum bangsa Indonesia sendiri, bersumber pada hukum yang hidup di masyarakat dan di rumuskan di dalam ketentuan hukum secara jelas dan tegas. Terkait dengan asas legalitas inilah maka larangan adat ini harus disebutkan dan dikenal dalam hukum adat yang tidak tertulis itu, demikian pula ancamannya. Penyebutan dan pengenalan larangan adat tidak tertulis ini memang begitu penting mengingat asas legalitas menghendaki adanya perlindungan bagi masyarakat yang akan mendapatkan kerugian atas hak yang dimilikinya ketika terjadi pelanggaran. Hal ini terkait dengan pengenaan sanksi adat yang lebih merupakan nestapa bagi pelanggarnya sehingga sebelum ia di kenai sanksi adat terlebih dahulu ia harus mengetahui larangan yang di maksudkan dan sanksi yang di ancamkan. Sanksi adat ini di maksudkan untuk mengembalikan keseimbangan kehidupan persekutuan masyarakat adat baik yang bersifat material atau immateriial ${ }^{10}$. Dalam pemahaman yang sama I Made Widnyana menegaskan delik adat ini sebagai

${ }^{8}$ Hwian Christianto, Pembaharuan Makna Asas Legalitas, dalam Jurnal Hukum \& Pembangunan, Tahun ke-39 No.3 Juli 2009, hal. 353-373.

${ }^{9}$ Andi Zainal Abidin Farid, "Hukum Pidana I", Cet. I, (Jakarta: Sinar Grafika Offset, 1995), hal. 144-147. hal. 67.

${ }^{10}$ Bushar Muhammad, "Pokok-pokok Hukum Adat", (Jakarta: Pradnya Paramita, 1983), 
Semua perbuatan atau kejadian yang bertentangan dengan kepatuhan, kerukunan, keamanan, rasa keadilan, dan kesadaran masyarakat yang bersangkutan, baik hal itu sebagai akibat dari perbuatan yang dilakukan seseorang, sekelompok orang maupun pengurus desa adat itu sendiri, perbuatan mana dipandang dapat menimbulkan kegoncangan karena mengganggu reaksi dari masyarakat berupa sanksi adat. ${ }^{11}$

Dari pendapat Widnyana ini di peroleh 3 (tiga) unsur penting, yaitu (1.) Perbuatan itu bertentangan norma-norma hukum adat; (2) Perbuatan itu dipandang dapat menimbulkan kegoncangan karena mengganggu keseimbangan dalam masyarakat dan (3). Atas perbuatan itu timbul reaksi dari masyarakat yang berupa sanksi adat. Dengan demikian sebenarnya pengakuan atas keberadaan hukum pidana adat ini sendiri juga tidak serta merta tetapi harus memenuhi ketiga persyaratan diatas.

Pemberlakuan hukum adat ini juga di akui secara tegas di dalam UU Darurat No. 1 Tahun 1951 terutama pada pasal 5 ayat (3) huruf b yang sebenarnya menunjukkan pemahaman hukum yang berlaku di Indonesia secara khusus hukum pidana tidak hanya undang-undang namun hukum adat yang hidup dan diakui di masyarakat. Hanya saja di dalam pelaksanaan hukum adat ini sangat berbeda dengan pelaksanaan KUHP. Perbedaan ini menyangkut sifat dan hakekat pemidanaan yang berlaku di kedua sistem hukum pidana itu. Di satu sisi, KUHP mendasarkan diri ancaman-ancaman pidananya pada apa yang tertera dalam asas legalitas yang menegaskan keharusan adanya suatu peraturan/undang-undang yang merumuskan secara terperinci perbuatan yang dilarang dan di jatuhi pidana. ${ }^{12}$ Sedangkan hukum pidana adat tidak memandang perlu ketentuan yang melarang perbuatan itu secara tertulis namun di dasarkan pada setiap warga harus mengetahui dan menyadari hukum yang hidup dalam lingkungan dimana ia menjadi warga. ${ }^{13}$ Perbedaan kedua tampak di dalam tujuan hukum pidana yang di harapkan, KUHP memberikan larangan dan sanksi dengan tujuan agar secara psikologis (psychologische zwang) setiap masyarakat akan takut untuk melakukan perbuatan yang dilarang sehingga bersifat preventif sedangkan didalam hukum pidana adat, setiap masyarakat menghindari larangan-larangan yang ada karena kesadaran diri sendiri dari setiap warganya.

\section{6.}

${ }^{11}$ I Made Widnyana, "Kapita Selekta Hukum Pidana Adat”, (Bandung: Eresco, 1993), hal.

${ }^{12}$ Hermien Hadiati Koeswadji, "Aspek Budaya dalam Pemidanaan Delik Adat", dalam BPHN, Simposium Pengaruh Kebudayaan/Agama terhadap Hukum Pidana, Cet. I, (Bandung: BinaCipta, 1975), hal. 50.

${ }^{13}$ Ibid. 


\section{Penemuan Hukum Pidana dalam Perkara Adat}

Seperti di jelaskan oleh Hermien H. Koeswadji, "pentaatan warga masyarakat atas ketentuan-ketentuan hukum adat yang tidak tertulis ini di sadari dan sudah menjiwai keseluruhan kehidupannya sebagai warga masyarakat yang baik, dan pentaatan kepadanya tanpa perlu adanya seorang penguasa atau seorang yang berwenang untuk mengawasinya". ${ }^{14}$ Perbedaan ketiga menyangkut wilayah pemberlakuan dari kedua sistem hukum pidana yang berbeda. Sistem hukum pidana secara tertulis (KUHP) mempunyai daya berlaku secara nasional dan siapa pun selama masih berada di wilayah Indonesia berlaku hukum pidana ini. Sangat berbeda dengan sistem hukum pidana adat yang hanya berlaku bagi masyarakat tertentu dan siapapun yang menundukkan diri kepadanya. Namun justru dari perbedaan-perbedaan inilah didapatkan suatu wilayah yang luas bagi hakim untuk melakukan penemuan hukum terkait perkara pidana adat atau delik adat yang di ajukan kepadanya. Seperti yang telah di jelaskan di awal, bahwa pemberlakuan ketentuan hukum adat tidak tertulis itu sebagai dasar mengadili sama sekali tidak melanggar asas legalitas. Justru pemberlakuan hukum adat tidak tertulis ini menjadi satu tanda yang baik di patuhinya asas legalitas. Apalagi UU Darurat No. 1 Tahun 1951 telah memberikan dasar hukum yang jelas untuk memberlakukan hukum adat sebagai dasar mengadili suatu perkara adat.

Hanya perlu di tekankan, meskipun hakim sudah memiliki kebebasan di dalam melakukan penemuan hukum di bidang hukum pidana adat tidak berarti secara serta merta hukum adat yang di tunjuk oleh hakim itu menjadi berlaku secara nasional. Penemuan hukum di dalam hukum pidana adat hanya berlaku bagi seseorang yang melanggar hukum adat suatu masyarakat dan menimbulkan kerugian bagi masyarakat adat. Oleh karena itu sesuai dengan pendapat yang di kemukakan Hermien $\mathrm{H}$. Koeswadji, seorang hakim yang memeriksa perkara pidana adat ini harus dengan yakin mengetahui adanya larangan yang berlaku di dalam masyarakat adat dan memahami anggapan atau perasaan hukum rakyat bahwa perbuatan yang di ajukan itu menentang hukum adat yang di akui ${ }^{15}$. Pengetahuan keberadaan hukum adat ini di ketahui ketika petugas hukum adat yang bersangkutan mempertahankannya terhadap orang yang melanggar peraturan itu atau ketika petugas hukum bertindak untuk mencegah pelanggaran hukum itu. ${ }^{16}$ Dari hal inilah seorang hakim dapat mengetahui ada atau tidaknya hukum adat di suatu masyarakat dan diakui keberadaannya.

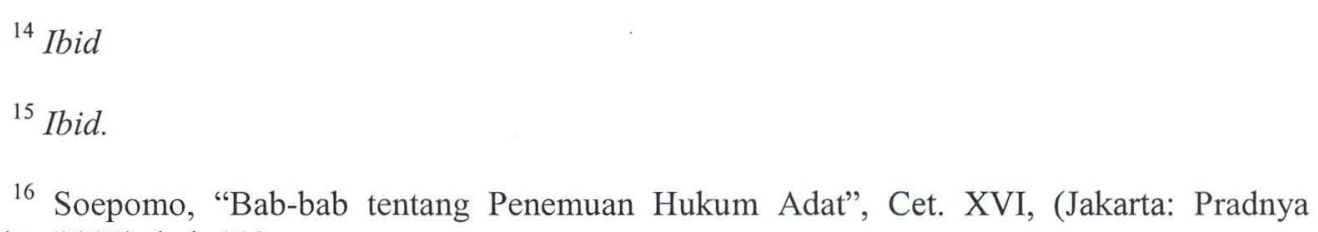
Paramita, 2003), hal. 113. 
Di dalam praktek pengadilan seringkali terjadi pertentangan antara sistim hukum tertulis dan sistim hukum pidana adat ketika menghadapi perkara pidana adat. Sebagai contoh dalam perkara pidana adat Bali dengan posisi kasus: ${ }^{17}$

Tertuduh II, Inaq P., sekalipun mempunyai suami, Inaq P. telah berbuat zina dengan laki-laki lain yang bukan suaminya sebanyak tiga kali, sehingga yang bersangkutan mendapat kenikmatan yang luar biasa, dan karenanya telah melanggar pasal 284 ayat 1-b KUHP jo. UU Darurat No. 1 Tahun 1951 atas perbuatan pidana adat yang di sebut sebagai "Bekekaruh".

Tertuduh I, sebagai seorang laki-laki telah turut serta melakukan perbuatan zina, sekalipun diketahui bahwa Tertuduh II telah mempunyai suami dari perkawinan yang sah, dan sebagai akibatnya rumah tangga suami Tertuduh II menjadi berantakan dan karenanya melanggar ketentuan pasal 284 ayat (1) Angka 2-a KUHP j.o. UU Darurat No. 1 Tahun 1951 atas perbuatan pidana adat yang di sebut "Bekekaruh".

Menurut pendapat ahli Kramadesa dari tempat perbuatan itu terjadi di nyatakan sebagai berikut:

a. Perbuatan yang dilakukan oleh Amaq N. dan Inaq P. adalah sangat berat, dan oleh karenanya kedua orang tersebut di buang (dikeluarkan) dari kedudukannya sebagai penduduk desa tersebut.

b. Apabila setelah selesai persoalan perkara ini Amaq P. (suami Tertuduh II) mengambil kembali Inaq P. menjadi istrinya maka Amaq P. juga akan di buang oleh penduduk dari desa tersebut.

Menurut hukum pidana adat yang berlaku perzinahan merupakan suatu perbuatan terkutuk dan melanggar hak dari suami. Oleh karena itu jika pelaku perbuatan perzinahan itu tertangkap tangan, menurut hukum adat si suami sangat berhak untuk membunuh isterinya dan laki-laki yang berzinah itu.

Di dalam putusannya hakim Pengadilan Negeri Bali ternyata sama sekali tidak menjadikan kesaksian ahli Kramadesa itu sebagai dasar hukumnya. Reaksi masyarakat pun pada akhirnya menolak putusan pengadilan dan lebih memberlakukan sanksi adat "bekekaruh" kepada kedua terpidana.

Dari perkara adat "bekekaruh" ini sebenarnya tindakan hakim untuk menghadirkan saksi ahli Kramadesa sudah menunjukkan suatu inisiatif untuk memahami nilai-nilai hukum masyarakat Bali tentang perzinahan. Seharusnya pula hakim menjadikan keterangan ahli ini sebagai dasar untuk mengadili perkara "bekekaruh" ini. Akibat yang di timbulkan dari putusan hakim ini sebenarnya sangat serius karena seolah-olah hukum pidana adat tidak di akui oleh hakim sebagai dasar hukum yang sah. Pemahaman ini akan membawa kesenjangan atau jarak antara hukum pidana tertulis dengan hukum pidana adat yang berakibat tidak di akuinya hukum pidana tertulis itu oleh masyarakat adat yang bersangkutan. Kondisi ini sebenarnya tidak perlu terjadi apabila hakim mampu memahami tugas dan kewajibannya untuk menggali nilai-nilai hukum di masyarakat dan

${ }^{17}$ Ibid, hal. 48-49. 
menerapkannya pada setiap kasus pidana adat yang di periksanya. Contoh lainnya di dalam perkara adat Bali $^{18}$ seperti:

1. Lokika Sanggraha (delik adat yang berupa seorang laki-laki menghamili seorang perempuan diluar perkawinan dengan janji akan mengawininya akan tetapi tidak di kawini), terhadap kasus ini Pengadilan Negeri Denpasar memberikan Putusan tertanggal 7 Juli 1969 yang menghukum penjara terdakwa selama 2 bulan dan di haruskan mengawini perempuan tersebut dan mengakui bahwa bayi yang lahir nanti adalah bayi terdakwa sendiri (dasar: Kitab Adi Agama bab/pasal Logika Sanggraha jo. UU Darurat No. 1 Tahun 1951 pasal 5 ayat (3) huruf b. Oleh masyarakat pun terdakwa di paksa untuk mengawini perempuan yang dihamilinya itu.

2. Amandel Sanggama (delik adat berupa seorang istri yang meninggalkan suaminya tanpa alasan di dalam ikatan perkawinan). Di dalam kasus ini, Pengadilan Negeri Denpasar mendasarkan diri pada UU Darurat No. 1 Tahun 1951 jo. Hukum Adat Amandel Sanggama.

3. Gamia Gemana (delik adat berupa larangan hubungan seksuil antara orangorang yang masih ada hubungan keluarga dekat). Oleh Pengadilan Negeri si pelaku di hukum masing-masing 6 (enam) tahun penjara berdasarkan Peswara 1927 jo UU Darurat No. 1 Tahun 1951. Di dalam perkara serupa juga di berikan sanksi:

a) Sanksi adat berupa tidak boleh masuk anggota banjar, denda atau di selong;

b) Sanksi: pelaku di mandikan ke laut (secara simbolik seperti ditenggelamkan ke laut), mengadakan upacara pembersihan dengan biaya sendiri) atau si pelaku diceraikan.

Di sinilah peran penting hakim dalam menampung setiap nilai-nilai hukum yang hidup di masyarakat di dalam setiap penemuan hukum yang diakukannya dan tertuang di dalam putusan-putusannya. ${ }^{19}$ Setiap putusan hakim yang mendasarkan diri tidak semata-mata pada hukum tertulis tetapi hukum adat akan membawa dampak keterbukaan dan pengakuan masyarakat adat pada sistem hukum pidana nasional. Meskipun demikian, hakim tetap harus mendasarkan dirinya secara utama pada Undang-undang yang berlaku seperti yang di maksud di dalam asas legalitas. Untuk berlaku seperti undang-undang, hukum adat itu harus di tunjuk/di berlakukan oleh undang-undang (seperti UU No. 1 Drt/ 1951).

Prinsip ini sebenarnya merupakan perwujudan dari asas legalitas di dalam hukum pidana yang menghendaki adanya kepastian hukum di dalam menentukan ada atau tidaknya peraturan yang di larang. Mochamad Zaidun menegaskan arti penting kepastian hukum ini melalui parameter yang harus ada di dalam hukum

18 Tjokora Raka D. \& I Made Widnyana, "Agama Hindu dan Hukum Pidana Nasional, di dalam BPHN", dalam Simposium Pengaruh Kebudayaan/Agama terhadap Hukum Pidana, (Bandung: Bina Cipta, 1975), hal. 118-119.

${ }^{19}$ Oemar Seno Adji, "Hukum (Acara) Pidana dalam Prospeksi”, Cet. IV, (Jakarta: Erlangga, 1984), hal. 171. 
pidana adat, meliputi Pertama terdapat masyarakat yang menjalankan suatu hukum tertentu, Kedua hukum adat itu selalu di patuhi dan berjalan di dalam hubungan bermasyarakat dan Ketiga, penegakan hukum ketika terjadi pelanggaran. ${ }^{20}$ Ketiga parameter ini menjadi dasar bagi hakim dalam menentukan ada atau tidaknya hukum adat yang berlaku di dalam perkara yang sedang di hadapinya. Di dalam syarat pertama, faktor masyarakat yang terdiri dari orangorang yang mengakui keberlakuan suatu hukum mutlak di perlukan. Mengingat lingkup keberlakuan dari hukum adat ini hanya pada masyarakat tertentu saja. Sebagai contoh di dalam masyarakat adat Bali dikenal suatu komunitas adat disebut Desa Adat yang merupakan persekutuan hukum yang keberadaannya dilandasi oleh adanya kehendak bersama dari orang-orang yang karena tuntutan kodratnya harus hidup bersama di dalam suatu wadah untuk mempermudah kepentingannya. $^{21}$

Pada syarat kedua, faktor pengakuan dan ketertundukan dari masyarakat terhadap hukum adat yang berlaku sangat menentukan bagi keberlakuan hukum adat sebagai pilihan hukum atas perkara yang terjadi (di dalam masyarakat adat Bali dikenal dengan awig-awig desa adat). Mochamad Zaidun menegaskan hal ini dengan adanya indikator "keajegan" dari masyarakat di dalam menyelesaikan perkara yang sama. $^{22}$

Sedangkan pada faktor ketiga, lembaga adat yang berfungsi sebagai penegak hukum apabila terjadi pelanggaran di munculkan sebagai bukti bahwa hukum adat harus di patuhi dan menimbulkan sanksi bila dilanggar. Dalam pemahaman yang sama Roeslan Saleh menyebut hal ini dengan "reaksi adat"23 yang di tandai dengan tindakan aparat penegak hukum adat. Faktor reaksi adat ini begitu penting mengingat delik adat lahir terus berkembang dan kemudian bisa lenyap di sebabkan hukum adat tidak mengenal sistim peraturan prae-existent ${ }^{24}$ yang mengatur perbuatan secara rigid.

Di dalam masyarakat hukum adat Bali lembaga adat ini dikenal dengan Prajuru Desa Adat, suatu struktur kepengurusan yang terdapat di dalam masyarakat (Kepala Desa Adat dan Sangkepan Desa Adat) yang mempunyai kekuasaan untuk menetapkan aturan-aturan untuk menjaga kehidupan organisasi secara tertib dan aman, kekuasaan untuk menyelenggarakan kehidupan organisasi yang bersifat sosial religius dan kekuasaan untuk menyelesaikan sengketa-

${ }^{20}$ Wawancara dengan Prof. Dr. Mochamad Zaidun, S.H.,M.Si., tema: Kebebasan Hakim di dalam Hukum Pidana, Fakultas Hukum Universitas Airlangga, 4 Juni 2009.

${ }^{21}$ I Made Widnyana, Eksistensi Delik Adat dalam Pembangunan, Orasi Pengukuhan Guru Besar Fakultas Hukum Universitas Udayana, Denpasar, tanggal 21 Juli 1992, hal. 17.

${ }^{22}$ Wawancara dengan Prof. Dr. Mochamad Zaidun,SH., M.Si., tema: Kebebasan Hakim di dalam Hukum Pidana, Fakultas Hukum Universitas Airlangga, 4 Juni 2009.

23 Roeslan Saleh, "Sifat Melawan Hukum dari Perbuatan Pidana", Cetakan Keempat, (Jakarta: Aksara Baru, 1983), hal. 15 \& 40.

${ }^{24}$ Ibid. 
sengketa atau tindakan yang menyimpang dari aturan yang telah dinilai mengganggu kehidupan masyarakat. Hanya saja mengenai macam pidana adat ini, sanksi adat yang harus di kenakan adalah sanksi delik yang serupa atau mirip dengan sanki yang di atur di dalam KUHP secara khusus Pasal 10. Pemahaman terhadap ketiga parameter ini sangat membuka peluang bagi hakim untuk menemukan hukum dengan sangat luas.

Hanya saja di dalam prakteknya tetap di batasi oleh Pasal 6 ayat (1) huruf a Undang-undang Darurat No. 1 Tahun 1951 yang mengakui tindak pidana adat dengan sanksi penjara tidak lebih dari 3 bulan. Di dalam menanggapi ketentuan hukum ini, hakim harus memperhatikan maksud pemberian sanksi ini untuk memberikan pelajaran bagi pelanggar agar tidak mengulangi perbuatannya dan sama sekali tidak bermaksud membatasi pidana yang bisa di jatuhkan oleh hakim. Hakim tetap mempunyai kebebasan dalam melakukan penafsiran terhadap hukum yang hidup di masyarakat dengan batasan Undang-undang Darurat Nomor 1 Tahun 1951 khususnya Pasal 6 ayat (1) huruf a.

Namun hal ini tidak berarti setiap nilai-nilai hukum pidana adat dapat secara langsung di terapkan menjadi dasar hukum mengadili suatu perkara adat. Hakim harus benar-benar mempertimbangkan beberapa faktor penting, seperti: ${ }^{25}$

1. Harus sesuai dengan nilai-nilai nasional (Pancasila), yaitu yang ber"Ketuhanan YME" (paradigma moral religius), ber- "Kemanusiaan yang adil dan beradab" (paradigma humanis), berorientasi pada nilai "persatuan (kepentingan bersama; paradigma kebangsaan)", nilai "kerakyatan/hikmah kebijaksanaan" (paradigma demokrasi) dan nilai/paradigma "keadilan sosial"

2. Sesuai dengan prinsip-prinsip hukum umum yang diakui oleh masyarakat bangsa-bangsa ("the general principles of law re-cognized by the community of nations")

Kedua hal ini sebenarnya merupakan suatu prinsip yang harus menjadi penyaring utama dalam menentukan nilai-nilai hukum yang berlaku di dalam hukum adat. Prinsip yang pertama lebih mengutamakan arah pembangunan hukum pidana nasional yang tetap mendasarkan diri pada nilai-nilai Pancasila namun tetap mengakui nilai-nilai hukum adat yang sesuai dengannya. Nilai-nilai Pancasila inilai yang di sebut sebagai cita hukum bagi bangsa Indonesia ${ }^{26}$ dalam mencapai masyarakat yang adil (weltenschauung bangsa Indonesia). Sedangkan prinsip yang kedua, lebih menujukkan komitmen bangsa Indonesia sebagai bagian dari masyarakat dunia dalam menghargai hak-hak manusia sebagai bangsa yang beradab.

25 Muladi, et.al., "Pengkajian Hukum tentang Asas-asas Pidana Indonesia dalam Perkembangan Masyarakat Masa Kini dan Mendatang", Badan Pembinaan Hukum Nasional Departemen Kehakiman RI, Jakarta, 2003, hal. 5.

${ }^{26}$ Roeslan Saleh, Pembinaan Cita Hukum dan Penerapan Asas-asas Hukum Nasional, di dalam BPHN, Majalah Hukum Nasional, No. 1 \&2, Jakarta, 1995, hal. 49. 
Di sinilah arti penting pemahaman secara mendalam tentang keberadaan hukum pidana adat itu sebagai salah satu sumber hukum pidana tidak tertulis yang seharusnya mendapatkan tempat di dalam pembangunan hukum pidana Indonesia. Pengakuan terhadap keberlakuan hukum pidana adat ini dengan sendirinya akan menumbuhkan peran serta masyarakat adat melalui lembaga adatnya untuk mengadakan penegakan hukum adat sekaligus perubahan hukum adat yang diperlukan. Hal ini tidak berarti tugas hakim menjadi hilang atau tidak berfungsi namun hakim tetap harus mengadakan penggalian nilai-nilai hukum adat yang berlaku di dalam masyarakat adat itu apabila terdapat kasus yang di ajukan padanya. Di dalam hal suatu perkara telah di putus dan di selesaikan di dalam lembaga adat maka terhadap tersangka tidak boleh di lakukan penuntutan ulang di Pengadilan Umum. Hal ini di dasarkan atas Putusan Mahkamah Agung Nomor: $1644 \mathrm{~K} / \mathrm{Pid} / 1988$ tanggal 15 Mei 1991 yang menegaskan tidak dapat menerima tuntutan jaksa penuntut umum atas diri terdakwa yang melakukan delik adat, karena terdakwa sebelumnya telah di jatuhi sanksi adat oleh Pemuka Adat dan sanksi adat tersebut telah dilaksanakan oleh terdakwa. Putusan ini sebenarnya merupakan perwujudan dari asas nebis in idem yang menghendaki kepastian hukum bagi seseorang untuk di tuntut di dalam perkara yang sama dan sekaligus mencerminkan pengakuan dari asas legalitas.

\section{Pengaturan Penemuan Hukum dalam Undang-undang Nomor 48 Tahun 2009}

Penemuan hukum merupakan salah satu tugas hakim yang paling utama ketika kepadanya dihadapkan sebuah kasus untuk diperiksa dan diberi putusan. Hanya saja sering terjadi Undang-undang sering tidak memberikan penjelasan yang rinci terhadap suatu kasus yang terjadi. Di dalam terjadinya memeriksa delik adat, hakim sebagai pelasaksana kekuasaan negara di bidang peradilan (pasal 24 ayat (1) UUD 1945 jo. Pasal 1 angka 1 UU No. 48 Tahun 2009) harus melakukan penemuan hukum yang berlaku di masyarakat. Ketika terdapat suatu kasus adat yang tidak terdapat ketentuan hukum yang jelas tetapi hakim berkeyakinan terdapat pelanggaran terhadap norma hukum yang berlaku di masyarakat hakim tidak boleh menolak untuk mengadili, memeriksa ataupun memutus perkara tersebut (Pasal 10 ayat (1) UU No. 48 Tahun 2009). Hakim dituntut untuk aktif menggali, mengikuti dan memahami nilai-nilai yang hidup dan berlaku di masyarakat (Pasal 5 ayat (1) UU No. 48 Tahun 2009) sehingga melalui ketentuan hukum ini hakim memiliki kewajiban untuk menggali dan memberlakukan hukum adat yang berlaku di masyarakat tidak hanya melulu Hukum yang tertulis.

\section{Penutup}

Kegiatan penemuan hukum oleh hakim di dalam perkara pidana adat sebenarnya sudah mendapatkan dasar hukum yang jelas di dalam pasal 5 ayat (1) juncto pasal 10 ayat (1) UU No. 48 Tahun 2009. Keberadaan pasal 5 ayat (3) huruf b UU Darurat No. 1 Tahun 1951 memang memberikan satu kemungkinan 
secara legal formal di akuinya hukum adat sebagai dasar mengadili bagi hakim. Namun di sisi lain akan mempersulit hakim dalam melakukan penemuan hukum di bidang hukum pidana adat ketika menentukan besarnya pidana. Mengingat di dalam pasal 6 ayat (1) huruf a UU Darurat No. 1 Tahun 1951 membatasi sanksi dalam kurun waktu 3 bulan dan denda lima ratus rupiah. Menurut hemat penulis, dengan UU No. 48 Tahun 2009 saja seorang hakim memperoleh dasar hukum yang sangat kuat untuk melakukan penemuan hukum di bidang pidana adat sehingga hakim dapat mengakomodasi kebutuhan dan perkembangan nilai-nilai hukum dan keadilan di masyarakat dalam pemberian sanksi. Dengan ketentuan hukum ini seorang hakim akan bebas mengadaptasikan nilai-nilai hukum adat yang di akui dan sudah ada di masyarakat dengan baik. 


\section{Daftar Pustaka}

\section{Buku}

Adji, Oemar Seno. Hukum (Acara) Pidana dalam Prospeksi, Cet. IV, Erlangga, Jakarta, 1984.

Apeldoorn, Van. Inleiding tot de studie van het Nederlandse Recht, $17 \mathrm{e}$ herziene druk, bewerkt door Mr. J.C.M. Leyten, Uitgeversmaatschappij W.E.J. Tjeenk Willink, Zwolle, 1972.

Bos, Alida M. Het Begrip Straffbaarfeit in de Rechtsvorming, KluwerDeventer, Netherland, 1971.

Farid, Andi Zainal Abidin. Hukum Pidana I, Cet. I, Sinar Grafika Offset, Jakarta, 1995.

Koentjoroningrat, Kebudayaan, Mentalitet dan Pembangunan, Jakarta: Gramedia, 1974.

Koeswadji, Hermien Hadiati, Aspek Budaya dalam Pemidanaan Delik Adat, dalam BPHN, Simposium Pengaruh Kebudayaan/Agama terhadap Hukum Pidana, Cet. I, Bandung: Bina Cipta, 1975.

Moeljatno. Asas-asas Hukum Pidana, Jakarta: Rineka Cipta, 2005.

Muhammad, Bushar. Pokok-pokok Hukum Adat, Jakarta: Pradnya Paramita, 1983.

Muladi et.al. Pengkajian Hukum tentang Asas-asas Pidana Indonesia dalam Perkembangan Masyarakat Masa Kini dan Mendatang, Badan Pembinaan Hukum Nasional - Departemen Kehakiman RI, Jakarta, 2003.

Saleh, Roeslan. Sifat Melawan Hukum dari Perbuatan Pidana, Cetakan Keempat, Jakarta: Aksara Baru, 1983.

Soepomo Bab-bab tentang Penemuan Hukum Adat, Cet. XVI, Pradnya Paramita, Jakarta, 2003.

Tjokora Raka D. \& I Made Widnyana. Agama Hindu dan Hukum Pidana Nasional, di dalam BPHN, Simposium Pengaruh Kebudayaan/Agama terhadap Hukum Pidana, Bandung: Bina Cipta, Bali, 1975.

Widnyana, I Made. Eksistensi Delik Adat dalam Pembangunan, Orasi Pengukuhan Guru Besar Fakultas Hukum Universitas Udayana, Denpasar, tanggal 21 Juli 1992. . Kapita Selekta Hukum Pidana Adat, Bandung: Eresco, 1993. 


\section{Jurnal Hukum}

Christianto, Hwian, "Pembaharuan Makna Asas Legalitas", dalam Jurnal Hukum \& Pembangunan, Tahun ke-39 No.3 Juli 2009.

Saleh, Roeslan. "Pembinaan Cita Hukum dan Penerapan Asas-asas Hukum Nasional", di dalam BPHN, Majalah Hukum Nasional, No. 1 \& 2, Jakarta, 1995.

\section{Sumber Wawancara}

Wawancara dengan Mochamad Zaidun, tema: "Kebebasan Hakim di dalam Hukum Pidana”, Fakultas Hukum Universitas Airlangga, 4 Juni 2009 